\title{
Asupan kalium-natrium dan status obesitas sebagai faktor risiko kejadian hipertensi pasien rawat jalan di RS Panembahan Senopati Bantul Yogyakarta
}

\author{
Sodium-potassium intake and obesity status as a risk factor of genesis hypertension outpatient \\ Panembahan Senopati Hospital Bantul Yogyakarta
}

\section{Effatul Afifah}

\begin{abstract}
Background: Hypertension is one of the problems in the medical and public health area. Based on National Health Research Association in 2013, hypertension is the third leading cause of death of all ages patterns, after stroke and TB, with the proportion of deaths was $6.8 \%$. The prevalence of hypertension in DIY was $25.7 \%$. The risk factors of diet containing high fat, high sodium, and low potassium to elevate blood pressure.

Objectives: To know the effect of the intake of sodium-potassium and the status of obesity as a risk factor for hypertension.

Methods: This study used analytic observational study design with control-case design. Samples were 104 and divided into 52 cases and 52 controls. Data were collected using a questionnaire include: name, age, gender, address, education level, the type of work, and form of food frequency questionnaire (FFQ) to inquire patterns of food intake (intake of sodium-potassium) for 3 months with food models. Obesity status was measured using body mass index (BMI), and merqurial sphygmomanometer hypertension was used to measure blood pressure. Analysis of data used statistical test independent $t$-test, chi-square.

Results: No significant correlation between age and the incidence of hypertension (OR=2.448), neither did sodium intake with hypertension, potassium intake with hypertension, and nutritional status (obesity) associated with the incidence of hypertension.

Conclusions: Age was the risk factor for hypertension, while the intake of sodium-potassium and status of obesity were not.
\end{abstract}

KEYWORDS: hypertension, sodium intake, potassium intake, obesity

\begin{abstract}
ABSTRAK
Latar belakang: Hipertensi merupakan salah satu masalah dalam dunia medis dan kesehatan masyarakat. Dalam riset kesehatan dasar nasional tahun 2013, hipertensi merupakan penyebab kematian semua umur yang ketiga, setelah stroke dan tuberculosis (TB), dengan proporsi kematian sebesar 6,8\%. Prevalensi hipertensi untuk wilayah DIY 25,7\% termasuk angka yang tinggi. Faktor risiko pola makan yang mengandung tinggi lemak, tinggi natrium dan rendah kalium memiliki kontribusi terhadap peningkatan tekanan darah.

Tujuan: Untuk mengetahui pengaruh asupan natrium, kalium, dan status obesitas sebagai faktor risiko hipertensi.

Metode: Penelitian ini menggunakan desain studi observasional analitik dengan rancangan kasus kontrol dengan jumlah total sampel 104 yang terbagi dalam 52 kasus dan 52 kontrol. Pengumpulan data menggunakan kuesioner meliputi: nama, umur, jenis kelamin, alamat, tingkat pendidikan, dan jenis pekerjaan dan formulir food frequency questionnaire (FFQ) untuk menanyakan pola asupan makanan (asupan natrium, kalium) selama 3 bulan menggunakan food model. Status obesitas diukur dengan
\end{abstract}

\footnotetext{
${ }_{1}$ Program Studi S1 IImu Gizi, Fakultas IImu-ilmu Kesehatan Universitas Alma Ata, Jl. Ring Road Barat Daya No 1, e-mail: effatulafifah@yahoo.com
} 
menggunakan indek massa tubuh (IMT) dan hipertensi diukur menggunakan merqurial sphygmomanometer. Analisis data menggunakan uji statistik independent t-test, chi-square.

Hasil: Ada hubungan yang signifikan antara usia dengan kejadian hipertensi $(O R=2,448)$. Asupan natrium tidak berhubungan signifikan dengan hipertensi. Tidak ada hubungan yang signifikan antara asupan kalium dengan hipertensi dan status gizi (obesitas) tidak berhubungan secara signifikan dengan kejadian hipertensi.

Kesimpulan: Usia merupakan faktor risiko kejadian hipertensi, sedangkan asupan natrium, kalium, dan status obesitas bukan merupakan faktor risiko hipertensi.

KATA KUNCI: hipertensi, asupan natrium, asupan kalium, obesitas

\section{PENDAHULUAN}

Indonesia mengalami masalah gizi ganda yang menurut Widya Karya Nasional Pangan dan Gizi sudah dimulai sejak tahun 1993. Hal ini berarti masalah kekurangan gizi belum bisa diatasi secara menyeluruh dan kini kelebihan gizi juga menjadi masalah. Masalah gizi tidak terlepas dari makanan karena masalah gizi timbul akibat kekurangan atau kelebihan kandungan zat gizi dalam makanan. Pola makan yang menjurus pada sajian siap santap yang mengandung lemak, protein, dan garam tinggi, tapi rendah serat membawa konsekuensi terhadap berkembangnya penyakit degeneratif seperti jantung, diabetes mellitus, kanker, osteoporosis, dan hipertensi (1).

Hipertensi merupakan salah satu masalah medis dan kesehatan masyarakat. Penyakit ini terus mengalami peningkatan prevalensi dan dapat meningkatkan risiko penyakit kardiovaskuler. Hipertensi diidentifikasi sebagai salah satu penyebab kematian di dunia serta menduduki peringkat ke-3 dalam angka kecacatan populasi (2).

WHO tahun 2000 menunjukkan bahwa sekitar 972 juta orang $(26,4 \%)$ penduduk bumi mengidap hipertensi. Perbandingan sekitar $26,6 \%$ pria dan $26,1 \%$ wanita. Dari 972 juta pengidap hipertensi, 333 juta berada di negara maju dan 639 berada di negara sedang berkembang (3). Berdasarkan riskesdas nasional tahun 2013, hipertensi merupakan pola penyebab kematian semua umur ketiga, setelah stroke dan tuberculosis (TB), dengan proporsi kematian sebesar $6,8 \%$. Adapun prevalensi nasional hipertensi pada penduduk umur $>18$ tahun adalah sebesar $25,8 \%$ (berdasarkan pengukuran). Prevalensi hipertensi untuk wilayah DIY 25,7\% termasuk angka yang tinggi (4).

Faktor penyebab terjadinya hipertensi antara lain kurangnya aktivitas fisik dan obesitas, kebiasaan merokok, keadaan stress, riwayat keluarga, dan kebiasaan mengonsumsi makanan tinggi lemak hewani, kurangnya serat, tinggi natrium, dan rendah kalium (5). Asupan natrium yang meningkat menyebabkan tubuh meretensi cairan, yang meningkatkan volume darah sehingga jantung harus memompa keras untuk mendorong volume darah yang meningkat melalui ruang yang makin sempit yang akibatnya adalah hipertensi. Penelitian epidemiologi menunjukkan bahwa asupan rendah kalium akan mengakibatkan peningkatan tekanan darah dan renal vascular remodeling yang mengindikasikan terjadinya resistansi pembuluh darah pada ginjal (6). Tekanan darah dapat meningkat salah satunya karena ketidakseimbangan kandungan kalium dan natrium dalam cairan intraseluler dan ekstraseluler. Rasio perbandingan antara kalium dan natrium adalah 1:1 (7).

Distribusi penyakit hipertensi esensial di Bantul, baik di puskesmas maupun rumah sakit termasuk dalam 10 besar penyakit tidak menular. Pada tahun 2013 kejadian hipertensi esensial di puskesmas se-Bantul mencapai 18.259 orang dan berdasarkan laporan sistem informasi rumah sakit (SIRS), distribusi kejadian hipertensi esensial di RSUD Panembahan Senopati Bantul mencapai 22.591 orang (8). Berdasarkan latar belakang tersebut, maka dianggap perlu untuk mengetahui rasio asupan konsumsi kalium natrium dan status obesitas terhadap kejadian hipertensi pada pasien 
rawat jalan RSUD Panembahan Senopati Bantul Yogyakarta.

\section{BAHAN DAN METODE}

Penelitian ini merupakan penelitian observasional analitik yang menggunakan rancangan kasus kontrol yang dilakukan di RSUD Panembahan Senopati Bantul pada periode pada bulan Juli hingga September 2015. Populasi penelitian ini adalah pasien rawat jalan di Poli Penyakit Dalam RSUD Panembahan Senopati Bantul Yogyakarta yang berjumlah 104 orang dengan jenis kelamin laki-laki dan perempuan. Subjek kasus adalah pasien hipertensi yang datang berobat (pasien baru) dan didiagnosis oleh dokter di Poliklinik Penyakit Dalam pada RSUD Panembahan Senopati. Subjek kontrol adalah pasien dengan diagnosis dokter tidak menderita atau bukan penderita hipertensi yang berobat di RSUD Panembahan Senopati Bantul sebagai pembanding kasus setelah melalui proses penyetaraan umur dan jenis kelamin. Pemilihan subjek penelitian berdasarkan kriteria inklusi yaitu pasien yang berobat di RSUD Panembahan Senopati Bantul berusia $\geq 30$ tahun hingga 60 tahun dan bersedia berpartisipasi dalam penelitian. Kriteria eksklusi yaitu pasien yang sedang menjalankan diet tertentu, sedang hamil dan menyusui dan menderita penyakit diabetes mellitus, kanker, ginjal, penyakit jantung koroner. Sampel diambil dengan cara non random sampling (by accidental sampling). Semua penderita yang didiagnosis hipertensi yang datang berobat ke RSUD Panembahan Senopati diwawancara dan langsung dicarikan kontrolnya yang sesuai untuk diteliti selanjutnya.

Variabel bebas penelitian terdiri dari asupan kalium, asupan natrium, dan status obesitas. Variabel terikat penelitian ini adalah hipertensi. Intake natrium adalah konsumsi rata-rata natrium per hari pria dan wanita dengan kriteria: lebih (jika asupan natrium=2.300 mg) dan kurang (jika asupan natrium $<2.300 \mathrm{mg}$ ). Asupan kalium adalah konsumsi rata-rata kalium per hari pria dan wanita dengan kriteria: lebih, jika asupan kalium $=2.000$ $\mathrm{mg}$ ) dan kurang (jika asupan kalium $<2.000 \mathrm{mg}$ (9).

Instrumen penelitian terdiri dari kuisioner data pribadi sampel penelitian meliputi: nama, umur, jenis kelamin, alamat, tingkat pendidikan, dan jenis pekerjaan, merquiral sphygmomanometer sebagai pengukur tekanan darah, formulir food frequency questionnaire (FFQ) untuk menanyakan pola asupan makanan (asupan natrium, kalium) selama 3 bulan terakhir beserta dengan food model, alat pengukur tinggi badan (microtoise) dengan ketelitian $0,1 \mathrm{~cm}$, alat timbang berat badan dengan ketelitian $0,1 \mathrm{~kg}$.

Analisis data status gizi ditentukan berdasarkan indeks massa tubuh (IMT). Data status gizi dilakukan dengan menggunakan program kalkulator IMT, pengukuran dilakukan dengan membandingkan berat badan (BB) dan tinggi badan (TB) dari sampel dengan kriteria: obesitas (jika IMT=25) dan tidak obesitas (jika IMT <25). Analisis data univariat dengan uji independent sample t-test dan analisis bivariat dengan uji chi-square. Analisis data menggunakan software SPSS 19.

\section{HASIL}

\section{Karakteristik subjek penelitian}

Sampel yang menderita hipertensi pada kelompok kasus dan kelompok kontrol lebih banyak yang berjenis kelamin perempuan. Namun demikian, hasil analisis statistik menunjukkan tidak ada perbedaan yang signifikan antara kasus (menderita hipertensi) dan kontrol (tidak hipertensi) berdasarkan jenis kelamin perempuan maupun laki-laki ( $p>0,05)$. Hasil analisis menunjukkan ada hubungan signifikan antara usia responden dengan kejadian hipertensi $(p<0,05)$ (Tabel 1).

Berdasarkan Tabel 2 diketahui bahwa tidak ada hubungan signifikan antara asupan natrium dan kalium dengan kejadian hipertensi $(p>0,05)$.

Berdasarkan Tabel 3 diketahui bahwa tidak ada hubungan signifikan antara status gizi responden dengan kejadian hipertensi $(p>0,05)$. 
Tabel 1. Hubungan karakteristik subjek dengan kejadian hipertensi

\begin{tabular}{|c|c|c|c|c|c|c|c|c|}
\hline \multirow{3}{*}{$\begin{array}{c}\text { Karakteristik } \\
\text { subjek penelitian }\end{array}$} & \multicolumn{4}{|c|}{ Kejadian hipertensi } & \multirow{2}{*}{\multicolumn{2}{|c|}{ Total }} & \multirow{3}{*}{$\begin{array}{c}\text { OR } \\
(95 \% \mathrm{Cl})\end{array}$} & \multirow{3}{*}{$\mathbf{p}$} \\
\hline & \multicolumn{2}{|c|}{ Kejadian hipertensi } & \multicolumn{2}{|c|}{ Tidak hipertensi } & & & & \\
\hline & $\mathbf{n}$ & $\%$ & $\mathbf{n}$ & $\%$ & $\mathbf{n}$ & $\%$ & & \\
\hline \multicolumn{9}{|l|}{ Jenis kelamin } \\
\hline Laki-laki & 40 & 76,9 & 14 & 26,9 & 54 & 51,9 & 1,5 & 0,821 \\
\hline Perempuan & 12 & 23,1 & 38 & 40 & 50 & 48,1 & & \\
\hline \multicolumn{9}{|l|}{ Usia responden } \\
\hline$>45$ tahun & 28 & 53,8 & 43 & 82,7 & 71 & 68,2 & 1,2 & 0,003 \\
\hline$\leq 45$ tahun & 24 & 46,2 & 9 & 17,3 & 33 & 31,7 & & \\
\hline
\end{tabular}

* Signifikan $(p<0,05)$

Tabel 2. Hubungan asupan zat gizi natrium dan kalium dengan kejadian hipertensi

\begin{tabular}{|c|c|c|c|c|c|c|c|c|}
\hline \multirow{3}{*}{ Asupan zat gizi } & \multicolumn{4}{|c|}{ Kejadian hipertensi } & \multirow{2}{*}{\multicolumn{2}{|c|}{ Total }} & \multirow{3}{*}{$\begin{array}{c}\text { OR } \\
(95 \% \mathrm{Cl})\end{array}$} & \multirow{3}{*}{$\mathbf{p}$} \\
\hline & \multicolumn{2}{|c|}{ Kejadian hipertensi } & \multicolumn{2}{|c|}{ Tidak hipertensi } & & & & \\
\hline & $n$ & $\%$ & $\mathbf{n}$ & $\%$ & $\mathrm{n}$ & $\%$ & & \\
\hline \multicolumn{9}{|c|}{ Tingkat asupan natrium } \\
\hline Lebih & 11 & 21 & 4 & 7,7 & 15 & 14 & 1,554 & 0,094 \\
\hline Cukup & 41 & 79 & 48 & 92,3 & 89 & 86 & & \\
\hline \multicolumn{9}{|l|}{ Tingkat asupan kalium } \\
\hline Lebih & 11 & 21 & 4 & 7,7 & 15 & 14 & 0,656 & 0,413 \\
\hline Cukup & 41 & 79 & 48 & 92,3 & 89 & 86 & & \\
\hline
\end{tabular}

* Signifikan $(p<0,05)$

Tabel 3. Hubungan status gizi dengan kejadian hipertensi

\begin{tabular}{|c|c|c|c|c|c|c|c|c|}
\hline \multirow{3}{*}{ Status gizi } & \multicolumn{4}{|c|}{ Kejadian hipertensi } & \multirow{2}{*}{\multicolumn{2}{|c|}{ Total }} & \multirow{3}{*}{$\begin{array}{c}\text { OR } \\
(95 \% \mathrm{Cl})\end{array}$} & \multirow{3}{*}{$\mathbf{p}$} \\
\hline & \multicolumn{2}{|c|}{ Kejadian hipertensi } & \multicolumn{2}{|c|}{ Tidak hipertensi } & & & & \\
\hline & $\mathbf{n}$ & $\%$ & $\mathbf{n}$ & $\%$ & $n$ & $\%$ & & \\
\hline Overweight & 15 & 28,8 & 13 & 25 & 28 & 26,9 & 1,216 & 0,825 \\
\hline Normal & 37 & 71,2 & 39 & 75 & 76 & 73,1 & & \\
\hline
\end{tabular}

\section{BAHASAN}

\section{Hubungan karakteristik subjek dengan kejadian hipertensi}

Beberapa penelitian sebelumnya menyimpulkan bahwa penderita hipertensi lebih banyak yang berjenis kelamin perempuan $(7,8,9)$. Secara keseluruhan, sampel yang didapat adalah yang bertempat tinggal di daerah sekitar Kabupaten Bantul. Perempuan yang tinggal di daerah perkotaan mau tidak mau harus berjuang untuk menghidupi keluarganya. Hal ini bisa menambah beban pikiran (stress) yang menyebabkan tingginya tekanan darah bila ditunjang juga dengan faktor risiko lainnya yaitu dari segi makanan (diet). Berdasarkan umur sampel yang hipertensi lebih banyak yang berusia
$>46$ tahun. Hasil analisis statistik juga menunjukkan tidak ada perbedaan yang signifikan antara kasus (menderita hipertensi) dan kontrol (tidak hipertensi) berdasarkan umur. Pada sampel yang hipertensi justru banyak yang berumur $>46$ tahun. Jika dihubungkan dengan jenis kelamin perempuan maka umur tersebut adalah rata-rata usia wanita menopause.

Menurut Kaplan (13), meningkatnya insiden hipertensi pada wanita adalah pada saat memasuki fase menopause. Pada masa menstruasi atau masa sebelum menopause, volume cairan dalam tubuh wanita tetap terjaga sehingga aliran atau tekanan hemodinamik (frekuensi nadi) tetap melambat, sehingga insiden hipertensi pada masa tersebut masih rendah. Wanita yang belum menopause 
tetapi telah menderita hipertensi didapati kadar hormon estrogennya lebih tinggi dibandingkan wanita yang tidak hipertensi. Menurut Elliot (14), dengan bertambahnya usia secara progresif maka dapat mengurangi elastisitas dari pembuluh darah yang mengakibatkan terjadinya kekakuan serta penyempitan. Hal ini berhubungan langsung dengan semakin tingginya resistensi dari pembuluh darah perifer dan meningkatnya tekanan darah.

Penelitian yang dilakukan pada populasi umum di Amerika Serikat menunjukkan hasil yang sama dengan penelitian ini, yaitu proporsi kasus hipertensi terbanyak terjadi pada sampel yang berumur 45-64 tahun dan berkurang pada usia $>75$ tahun (15). Penelitian yang dilakukan pada masyarakat tradisional Melanesia di Papua New Guinea menunjukkan tekanan darah sistolik mengalami peningkatan secara linear setelah usia 50 tahun pada pria dan wanita (16).

\section{Hubungan asupan zat gizi kalium dan natrium dengan kejadian hipertensi}

Hasil analisis bivariat menunjukkan bahwa asupan natrium pada kelompok kontrol dan kasus secara statistik tidak berhubungan dengan kejadian hipertensi $(p>0,05)$. Nilai $O R=1,554$, 95\% Cl:0,416-5,800 berarti kecenderungan untuk terkena hipertensi adalah 1,5 kali lebih besar bila dibandingkan dengan kelompok yang memiliki asupan natrium $<2.300 \mathrm{mg}$. Proporsi kasus (menderita hipertensi) yang memiliki asupan natrium $\geq 2.300 \mathrm{mg}$ hampir sama banyak dengan proporsi pada kelompok kontrol (tidak hipertensi). Hal ini diduga yang menyebabkan tidak adanya hubungan yang bermakna terhadap kejadian hipertensi.

Berdasarkan hasil wawancara, rata-rata asupan natrium pada kelompok kasus didapatkan dari konsumsi mie instan dan pemakaian bumbu penyedap banyak digunakan. Mie instan juga terkadang dikonsumsi sehari-hari jika ingin dikonsumsi, karena mudah diperoleh dengan harga yang relatif murah (untuk mie instan) dibandingkan makanan sumber natrium lainnya. Pada kelompok kontrol, rata-rata asupan natrium didapat dari konsumsi makanan sumber jeroan, serta pemakaian bumbu penyedap. Frekuensi konsumsi serta penggunaan bahan makanan sumber natrium sering ditemukan setiap harinya. Untuk makanan jadi yang paling banyak dikonsumsi adalah sejenis mie instan dan makanan fast food. Minuman kaleng lebih banyak dikonsumsi hanya pada hari raya dan untuk minuman susu lebih banyak dikonsumsi.

Asupan natrium yang tinggi ( $\geq 2.300 \mathrm{mg}$ ) bila ditunjang dengan menurunnya adaptasi ginjal dapat menyebabkan retensi natrium pada ginjal dan juga membuat kalium yang tersimpan dalam tubuh menjadi berkurang. Hal ini mengakibatkan perpindahan volume cairan ekstraseluler sehingga terjadi pembebasan faktor yang berhubungan dengan $\mathrm{Na}^{+} / \mathrm{K}^{+}$. Kelebihan natrium dan kekurangan kalium dalam sel mengakibatkan terjadinya kontraksi sel pembuluh darah. Adanya kontraksi pembuluh darah mengakibatkan peningkatan resistensi pembuluh darah perifer yang berakhir pada terjadinya hipertensi (17).

Penelitian yang dilakukan pada lansia di Bengkulu mendapatkan hasil yang berbeda dengan penelitian ini (18). Penelitian tentang hipertensi tersebut menyimpulkan bahwa mereka yang hipertensi rata-rata memiliki asupan natrium $\geq 2.300 \mathrm{mg}$ dan memiliki risiko 3,43 kali terkena hipertensi. Appel menyimpulkan bahwa penurunan asupan natrium merupakan salah satu terapi non farmakologis pada usia lanjut yang sangat efektif dalam menurunkan tekanan darah dan mengontrol tekanan darah (19).

Hal ini berbeda dengan penelitian yang dilakukan pada pasien rawat jalan di RSUD Kabupaten Karanganyar yang menunjukan bahwa pola konsumsi makanan sumber natrium merupakan faktor yang berhubungan dengan kejadian hipertensi $(p=0,004, O R=6,875)(20)$. Sama halnya dengan penelitian lain yang menyebutkan menunjukan asupan natrium merupakan faktor risiko paling kuat (OR=7,389, 95\% Cl:1,875 - 29,111) terhadap kejadian hipertensi (21).

Asupan natrium yang tinggi diperoleh dari bahan makanan seperti garam dapur, kecap, saus tomat, MSG (monosodium glutamat), makanan olahan yang diawetkan seperti ikan asin, makanan kaleng (corned beef, ham), buah kaleng, biskuit kaleng, sosis, keju, lemak babi, jeroan. Di antara 
makanan yang belum diolah, sayuran dan buah mengandung paling sedikit natrium (22). Dengan mengurangi asupan natrium melalui perencanaan pola makan berdasarkan DASH diet, diharapkan dapat mencegah terjadinya hipertensi secara non farmakologis (23).

Berdasarkan hasil analisis bivariat pada penelitian ini, asupan kalium tidak berhubungan secara statistik dengan kejadian hipertensi $(p>0,05)$, nilai $\mathrm{OR}=0,656,95 \% \mathrm{Cl}=0,292-1,473$. Kelompok hipertensi (kasus) dan kelompok kontrol mempunyai rata-rata asupan kalium $\geq 2.000 \mathrm{mg}$ yang jumlahnya hampir sama. Hal ini disebabkan lebih banyak kasus yang mengonsumsi makanan yang kurang sumber kalium (sayuran dan buah). Pada kelompok kontrol, lebih banyak sampel yang memiliki asupan kalium $\geq 2.000 \mathrm{mg}$. Asupan kalium didapat dari jenis sayuran yang berupa bayam, kangkung, daun singkong, daun papaya, dan sayuran lain. Sayur yang dikonsumsi kurang beraneka ragam dan hanya dimakan sesekali saja. Untuk jenis buah yang paling sering dikonsumsi adalah pisang dan mangga.

Asupan kalium baik pada kelompok kontrol dan kasus termasuk kategori cukup karena pola makan buah yang tidak bervariasi. Walaupun demikian, pada kedua kelompok tersebut sudah mempunyai kebiasaan mengonsumsi sayur yang baik. Untuk konsumsi makanan pokok sumber karbohidrat yang dikonsumsi antara lain: umbi-umbian, nasi, beras, dan mie. Makanan sumber kalium hanya dimakan sebagai makanan pendamping saja dan bukan sebagai makanan utama dalam penyajiannya.

Kalium adalah salah satu mineral makro yang dibutuhkan oleh tubuh dan terdapat di dalam sel. Bersama natrium, kalium memegang peranan dalam pemeliharaan keseimbangan cairan dan elektrolit serta keseimbangan asam basa (22). Fungsi kalium juga untuk mengatur keseimbangan jumlah natrium dalam sel (24). Salah satu akibat kekurangan asupan kalium adalah menurunnya kemampuan jantung dalam memompa darah. Asupan kalium bisa didapat dari mengonsumsi berbagai sayur dan buahbuahan (22). Kalium berperan dalam menurunkan tekanan darah. Penelitian cross sectional di daerah California Selatan sejalan dengan penelitian yang dilakukan oleh Khaw dan Barret-Connor yang menemukan bahwa terdapat korelasi yang langsung pada tekanan darah diastolik dengan asupan kalium pada pria dan wanita (25). Setelah umur diatur, tekanan darah sistolik dan diastolik memiliki korelasi yang signifikan dengan rasio kalium natrium. Peningkatan rasio natrium-kalium dapat meningkatkan level tekanan darah sistolik bahkan yang masih di bawah $140 \mathrm{mmHg}$. Menurut Susalit (26) penambahan asupan kalium akan menurunkan natrium intranse dengan cara aktivasi pompa Na-KATP yang akan mengakibatkan pengurangan efek peninggian tekanan darah oleh karena tingginya asupan natrium.

\section{Hubungan status gizi dengan kejadian hipertensi}

Hasil analisis berdasarkan status gizi menunjukkan bahwa kejadian hipertensi pada kelompok kasus dan kelompok kontrol tidak ada perbedaan signifikan dengan nilai $p(>0,05)$ OR=1,216, 95\% Cl:0,510-2,898. Jumlah responden yang mengalami hipertensi pada kelompok kasus sebesar $28,8 \%$, hampir sama dengan kelompok kontrol yang sebesar $25 \%$. Hal ini menunjukkan bahwa variabel status gizi bukan merupakan faktor risiko kejadian hipertensi.

Pembahasan hipertensi primer tidak disebabkan oleh faktor tunggal dan khusus, tetapi disebabkan berbagai faktor yang saling berkaitan. Risiko relatif hipertensi tergantung pada jumlah dan keparahan dari faktor risiko yang dapat dimodifikasi dan yang tidak dapat dimodifikasi. Faktor-faktor yang tidak dapat dimodifikasi antara lain faktor genetik, umur, jenis kelamin, dan etnis, sedangkan faktor yang dapat dimodifikasi meliputi stres, obesitas, dan nutrisi (27).

\section{KESIMPULAN DAN SARAN}

Kejadian hipertensi cenderung lebih banyak terjadi pada individu yang berjenis kelamin wanita dibandingkan laki-laki, tetapi pada penelitian ini jenis kelamin bukan faktor risiko kejadian hipertensi. Usia merupakan faktor risiko terjadinya hipertensi. Semakin tua individu, semakin berisiko untuk terjadi hipertensi. Asupan natrium $>2.300 \mathrm{mg}$ 
bukan merupakan faktor risiko terjadinya hipertensi. Asupan kalium $<2.000 \mathrm{mg}$ bukan merupakan faktor risiko terjadinya hipertensi. Status gizi (overweight dan obesitas) bukan merupakan faktor risiko terjadinya hipertensi.

Saran untuk penelitian selanjutnya dilakukan proses matching yang lebih detail agar subjeknya lebih homogen. Subjek penelitian diharapkan berjenis kelamin laki-laki karena tidak terpengaruh oleh hormon menopouse.

\section{RUJUKAN}

1. Muhammadun. Hidup bersama hipertensi. Yogyakarta: In-Books; 2010.

2. Kearney P, Perry I. Regional differences in blood pressure in developed countries. Comprehensive Hypertension. USA: Mosby Elsevier; 2007.

3. Farmaci. Konas InaSH (Indonesia Society of Hypertension) I, panduan dalam upaya pengendalian hipertensi. Simposia. 2007;6(7).

4. Badan Penelitian Dan Pengembangan Kesehatan Kementerian Kesehatan RI. Riset kesehatan dasar 2013. Jakarta: Balai Penelitian dan Pengembangan Kesehatan Rl; 2013.

5. Lipoeto N. Kejadian hipertensi dan beberapa faktor resikonya di padang. Universitas Andalas; 2002.

6. Lestari D. Hubungan asupan kalium, kalsium, magnesium, dan natrium, indeks massa tubuh, serta aktifitas fisik dengan kejadian hipertensi pada wanita usia $30-40$ tahun. Universitas Diponegoro; 2010.

7. Shinya $H$. The miracle of enzyme. Bandung: Penerbit Qanita PT Mizan Publika; 2008.

8. RSUD Panembahan Senopati. Laporan sistem informasi rumah sakit (SIRS). Bantul: RSUD Panembahan Senopati Bantul; 2013.

9. Proboprastowo, SM, Dwiriani C. Angka kecukupan air dan elektrolit. WNPG VIII Ketahanan Pangan dan Gizi di Era Otonomi Daerah dan Globalisasi. Jakarta: Depkes, Badan POM, Bappena, Deptan, Ristek; 2004.

10. Santoso M, Lyta, Pina. Gambaran pola komplikasi penderita hipertensi yang dirawat di
RSUD Koja 2000-2004. Cermin Dunia Kedokt. 2006;150:47-9.

11. Mizwar. Faktor-faktor risiko terjadinya hipertensi esensial di Kabupaten Klaten. Universitas Gadjah Mada; 2004.

12. Méndez-Chacón E, Santamaría-Ulloa C, RoseroBixby L. Factors associated with hypertension prevalence, unawareness and treatment among Costa Rican elderly. BMC Public Health [Internet]. 2008 Dec 5;8(1):275. Available from: http://bmcpublichealth.biomedcentral.com/ articles/10.1186/1471-2458-8-275

13. Kaplan N. Hypertensive and atherosclerotic cardiovaskuler disease. Heart disease: a text book of cardiovascular medicine, 6th.ed. Philadelphia: Elsevier Saunders; 2001.

14. Elliot H. Epidemiology, aetiology and prognosis of hypertension. London: The Medicine Publishing Company; 2002.

15. He J, Muntner P, Cheng J, Roccella E, Streiffer R, Whelton P. Factors associated with hypertension control in the general population of the United States. Arch Intern Med. 2002;162:1051-208.

16. Lindeberg A, Berntrop E, Ehle-Nilson P, Terent A, Vessby B. Age relations of cardiovaskuler risk factors in a traditional Melanesian society : the Kitava study. Am J Clin Nutr. 1997;66(4):84552.

17. Adrogue $H$, Madias N. Sodium and potassium in the pathogenesis of hypertension. NEJM. 2007;356:1966-78.

18. Riyadi A, Wiyono P, Budiningsari R. Asupan gizi dan status gizi sebagai faktor risiko hipertensi esensial pada lansia di Puskesmas Curup dan Perumnas Kabupaten Rejang Lebong Propinsi Bengkulu. J Gizi Klin Indones. 2007;4(1):4351.

19. Appel L, Espeland M, Easter L, Wilson A, Folmar $S$, Lacy $C$. Effects of reduced sodium intake on hypertension control in older individuals. Arch Intern Med. 2001;161:685-93.

20. Hiroh A. Faktor-Faktor yang berhubungan dengan terjadinya hipertensi pada pasien rawat jalan di RSUD Kabupaten Karanganyar. Universitas Muhammadiyah Surakarta; 2012. 
21. Hermawan E, Sulchan M. Faktor determinan gizi kejadian hipertensi. Universitas Diponegoro; 2007.

22. Almatsier S. Prinsip dasar ilmu gizi. Jakarta: PT Gramedia Pustaka Utama; 2004.

23. Eley R. DASH eating plan. USA: U.S. Department Of Health And Human Services National Institutes of Health National Heart, Lung, and Blood Institute; 2006.

24. Sheps, Sheldon G. Mayo clinic hipertensi, mengatasi tekanan darah tinggi. Jakarta: PT Intisari Mediatama; 2005.
25. Khaw K, Barret-Connor E. Association between blood pressure, age, and dietary sodium and potassium: a population study. Circulation. 1988;77:53-61.

26. Susalit E, Kapojos E, Lubis H. Hipertensi primer. Buku Ajar Ilmu Penyakit Dalam, Edisi III. Jakarta: Balai Penerbit FKUI; 2001. p. 453.

27. Anggraini F. Hubungan antara gaya hidup dengan status kesehatan Lansia Binaan Puskesmas Pekayon Jaya Bekasi tahun 2008. Universitas Indonesia; 2008. 